\title{
Enacting entrepreneurship research in a pioneering, provocative and participative way: on the work of Bengt Johannisson
}

\author{
Chris Steyaert · Hans Landström
}

Accepted: 1 March 2009/Published online: 12 June 2009

(C) Springer Science+Business Media, LLC. 2009

\begin{abstract}
Bengt Johannisson received the International Award for Entrepreneurship and Small Business Research in 2008. In this essay we present and evaluate his work over the last four decades in three of its dimensions: pioneering, provocative and participative. While his research interests and themes range widely, early on he resisted the individualization of entrepreneurship studies and instead emphasized that entrepreneurship is a social practice that must be contextualized, localized and situated. In so doing, he uses such concepts as networks, industrial districts, regions and local communities. Making interpretive studies possible in a European context, his conceptual and methodological approach documents how future studies of entrepreneurship can be enacted as a reflexive, participative practice where methods of research, intervention and debate become blurred.
\end{abstract}

C. Steyaert ( $\square)$

University of St. Gallen, Varnbüelstrasse 19, St. Gallen,

Switzerland

e-mail: chris.steyaert@unisg.ch

H. Landström

Lund University, Box 7080, Lund, Sweden

e-mail: hans.landstrom@fek.lu.se
Keywords Interpretive turn - Organizing · Enactive research · Networking · Regional development $\cdot$ Curiosity

JEL Classifications $\quad$ M13 $\cdot$ M26 $\cdot$ L26

\section{Introduction}

When Bengt Johannisson received in 2008 the International Award for Entrepreneurship and Small Business Research (from 2009 the Global Award for Entrepreneurship Research), the Prize Committee broke with the implicit rule that this Sweden-based Award could not be granted to a Swedish citizen. Rather than confirm the saying that it is hard to be a prophet in one's own country, the jury acknowledged both the international visibility of Johannisson's academic work and its impact on the research and practice of entrepreneurship in the Swedish research landscape (Johannisson 1987a; Landström and Johannisson 1999) and more generally in the Scandinavian context (Johannisson 1995b; Johannisson and Mønsted 1997; Hjorth et al. 2003). If a European School of entrepreneurship exists (Johannisson 1999; Hjorth et al. 2008) in which Scandinavian thinking clearly predominates along with a Swedish theoretical platform (Landström and Johannisson 2001), then it was instigated by the pioneering, provocative 
and participative work of Johannisson, as the laudatio of the prize committee confirms:

Professor Johannisson has been a very active participant and has played a key role in the development of the European entrepreneurship and small business research tradition. He has been influential both through a vast scientific production and through his strong "presence" in the scientific discourse by his dedicated participation in conferences, seminars for doctoral students, as invited lecturer and through his general interest in the debate on this particular field of research.

Bengt Johannisson is well known internationally for his ten years service as general editor of the journal Entrepreneurship and Regional Development (1998-2007), one of the few European-led journals with an SSCI imprimatur. Probably no journal title can better summarize his work than one that combines the topics of entrepreneurship and regional development. We will structure our analysis of his work around the broad themes of entrepreneurship and regional development and will also argue that his contribution lies in the continuing connections he has produced by emphasizing the situated nature of the entrepreneurial process. That is, his processual, interpretively-based approach to entrepreneurship has influenced the understanding of networking practices and regional development, while his theoretical understanding of network-based entrepreneurship has influenced his own auto-ethnographical, entrepreneurial practices and experiments, which aim at doing research close to where things happen.

As a consequence of relating entrepreneurship theory to practices of networking, his work can be said to have early on resisted the individualization of entrepreneurship because "networks and networking provide excellent fora to investigate the 'social' in entrepreneurship" (Jack et al. 2008, p. 125). Instead, Johannisson emphasizes that entrepreneurship is a social practice that needs to be contextualized, localized and situated by drawing upon and empirically grounding such concepts as networks (Johannisson 1995b), industrial districts (Johannisson and Spilling 1986), regions (Johannisson 1983a) and local communities (Johannisson and Nilsson 1989). It also needs to be studied as a reflexive practice where methods of research and intervention are connected in what he likes to refer to with neologisms such as "reflaction" or "creactivity", and "auto-ethnography" and "ongoing enactments". Through this close connection, theory and practice have become, in the words of Geertz (1983) "blurred genres".

\section{Between pioneering, provocation and participation}

Bengt Johannisson can be regarded as one of the real pioneers in European entrepreneurship and small business research; for almost four decades he has stimulated and provoked researchers within the field as well as policy-makers and practitioners through his writing and active participation in debates on entrepreneurship and small business in society. In our view, his work can be summarized and discussed around the intertwined dimensions of pioneering, provocation and participation.

First, in what some might see as a mere truism or a shallow analogy to the entrepreneurial phenomenon, we assess his contribution as a pioneer, as his curriculum includes many "firsts" and "originals". Consider some of his pioneering achievements. 1) He was one of the first entrepreneurship and small business researchers in Scandinavia to get his research internationally recognized by publishing it in international scientific journals. 2) In 1975 he initiated the first academic small business program at Växjö University and in 1980 organized the first university doctoral course in entrepreneurship and small business management in Sweden. 3) Early on he became involved in the European Doctoral Programme in Entrepreneurship and Small Business Management, which aims to develop scholars and promote research in the field of entrepreneurship (for a history, see Urbano et al. 2008). ${ }^{1}$ 4) He co-wrote the first article in the first issue of Entrepreneurship and Regional Development (Johannisson and Nilsson 1989). Most important, in 1989 he was the first person in Sweden to occupy a chair in entrepreneurship and business development at Lund University and Växjö University, and thus one of the first in the whole of Europe.

\footnotetext{
${ }^{1}$ Since the mid-1990 s it has been jointly organized by Universitat Autonoma de Barcelona, in Spain and Växjö University in Sweden.
} 
Second, his work can be called provocative. Etymologically, provocation means "calling forth", giving rise to feelings and actions, inciting others to activity, if not activism, or stirring the pot to move things and people. Taking as much advantage of his own pioneering position as of his genuine scientific curiosity, Johannisson enacts provocation: he likes to use his voice in academic, local and personal debates and moves people with his sharp and humorous comments. He saw that if entrepreneurship studies needed to be based on entrepreneurial practice itself, that pioneering practice would require a form of curiosity, radicality and confrontation that allows one to question the taken-for-granted assumptions of knowing and the usual ways of proceeding. Even more than the written word, Johannisson engages with what we would like to call a "practice of voicing at conferencing": he is regularly invited not only to be a keynote speaker (e.g. Johannisson 1999, 2002a) but also a panel member who can be counted on to be thought-provoking, witty and confrontational, voicing new ideas which he underscores with challenging stances and personal opinions. Taking advantage of a rhetorical gift, he playfully teases out the possibilities of language so that language itself becomes an instrument for understanding entrepreneurship. Moreover, his reference list is populated-more than some would find acceptable in the current climate of toptier publishing-with conference papers, many of them undertaken with doctoral students. This was and continues to be his way to explore and present emerging ideas or concepts at the edge of habitual conceptualizations and to use his experience and status to provide some space and leverage for the emerging scholarly voices of doctoral students.

Third, if this provocative style has resulted in a somewhat idiosyncratic academic performance, Johannisson seems not to fulfill the cliché of the lonely pioneer but has, through the years, developed a participative stance. Rejecting any position as an armchair scientist, he has always been eager to get closer to the phenomena he studied as they evolved. For instance, rather than orient his interest in networks towards an abstract effort at modeling, he engaged in the question of how networks unfold in a contextualized process. Thus he turned towards ideographic methodologies, used participative methodological approaches, and supported the interpretive paradigm; by doing the latter he helped facilitate the emergence of a multi-paradigmatically conceived entrepreneurship, one that can also be approached in an "advanced" way using qualitative methods.

Like many other pioneers in entrepreneurship and small business research (Landström 2005), Johannisson has extended his work over many different research themes and questions, including regional development, personal networks, social entrepreneurship, family businesses, entrepreneurial learning and teaching, and types of entrepreneurs including women, immigrants and community members. To do so he has used a variety of conceptual and methodological approaches, from advanced statistical analysis to qualitative action-oriented approaches. In this review we focus primarily on two interwoven areas of interest: his interest in entrepreneurship as a "contextualized practice", illustrated by the connection between networking and local development, and the conceptual/methodological concerns that arise while conducting contextual, interpretive studies with a social ontology. This choice is based on the fact that Johannisson's research career bears the stamp of his research achievements during the late 1970s and 1980s, both thematically with a focus on local development and personal networks as well as the switch, conceptually and methodologically, to interpretive and action research approaches.

\section{Contextualizing entrepreneurship: from personal networks to local development}

Early on, the thematic focus of Johannisson's work was on local development and personal networks, which implied a sensitivity for contextualizing the research design. One of his first attempts to contextualize research projects concerned some early empirical studies in a few small rural communities in Sweden (Johannisson 1983a, 1984; Johannisson and Spilling 1986). ${ }^{2}$ Focusing on the networks that emerged among small business managers in these various communities, he used a systems model to illustrate how spatial clusters of firms combine into production systems. In these initial attempts, he aligned his work with both national and international

\footnotetext{
${ }^{2}$ One of them is Gnosjö, arguably the most famous industrial district in Sweden dominated by metal engineering and plastic firms.
} 
research agendas and in the decades to come he was able to claim a core stake in the debates on entrepreneurial networking (Jack et al. 2008).

\subsection{Local networks on the (international) research agenda}

With his focus on local networks, Johannisson was quick both to grasp the local interests and to align himself with an emerging focus on the international research scene. Many factors made it particularly feasible to study both the local aspects and the network approach in the Swedish context (see Johannisson and Mønsted 1997). First, given Sweden's vast geography and sparse population, the local and regional aspects of entrepreneurship and small business activities have always been of interest. Also, Swedes see their small business sector as an important provider of employment; this perception became even more popular after Birch's study on the relationship between SMEs and job creation (Birch 1979) and gained momentum as a research topic during the 1980s. The regional interest in business formation was also addressed early among scholars from various disciplines (Johannisson 1987a). Moreover, the business community and the local community are closely intertwined in the Swedish corporatist welfare state, so the network approach is particularly appropriate for studying this connection. Thus, many reasons linked to Swedish society may explain Johannisson's interest in networks, especially in the local context. Another reason, however, may be the scientific interest in management studies in Sweden at that time. Management scholars in Sweden were quick to adopt the reasoning of Glaser and Strauss (1967) about "grounded theory" and ever since, the qualitative research tradition has been strong. The qualitative approach made it possible to grasp the complexity of the local networks.

Against this Swedish background, we must recall that scholars around Europe were then increasingly interested in studying entrepreneurship and small businesses in a regional context (Karlsson et al. 1993). In that sense Johannisson's research can be regarded as engaging with an emerging, dominant theme in the late 1970s and the 1980s (Landström 2005). However, the phenomenon of geographical concentration has fascinated scholars since Weber's (1909) location theory, which paved the way for the perspective of economic geography. Also crucial is the work of Marshall (1919) who proposed the notion of industrial districts-characterized by economies of specialization, information and labor supply, embedded in an "industrial atmosphere". The focus on industrial districts was reinforced during the 1970s through writings by Italian economists, notably Giacomo Becattini and Sebastiano Brusco (e.g., Becattini 1989; Brusco 1989). However, it was not until Michael Piore and Charles Sabel published The Second Industrial Divide in 1984 that the concept of industrial districts and the interest in regional development received international attention (Goodman et al. 1989). It is in this historical context that Johannisson's early research achievements should be seen.

Similarly, it can be said that studies on the relationship between entrepreneurship and networks were already in vogue internationally in the entrepreneurship and small business research of the time. Researchers recognized that entrepreneurship was not only an individual achievement but also a social phenomenon in which the entrepreneur's network plays an important role. According to Johannisson (1988), entrepreneurs could be seen as both autonomous and externally controlled and as using their networks in both reactive and proactive ways. Johannisson concentrated on the networking practices themselves at a time where it was common to study personal features of entrepreneurs-notice this is the time when Gartner (1988) objected against this trend in his infamous article entitled "Who is the entrepreneur is the wrong question" (Steyaert 2007b).

In contrast to Johannisson, Anglo-Saxon researchers (e.g., Birley 1985; Aldrich and Zimmer 1986) focused more on how the network metaphor could function as an individual management strategy; drawing upon a resource-dependence perspective, they said entrepreneurs use networks primarily to complement their own limited resources, and function as basically rational economic actors. Instead, Johannisson looked into the paradoxical features of networking, finding room both for spontaneous and calculated interaction and for reactive and proactive strategies. That also let him avoid a rational and deterministic view of human action and partially underlined "the notion of individuals as free creators of their own destiny" (Johannisson 1995a, p. 218). In this regard, he followed Gartner et al. (1992, p. 218) 
who believes that entrepreneurs can oppose determinism "by acting 'as if' reality was open-ended until it is defined by themselves - they create 'enacted environments' and behave accordingly".

\subsection{Personal networks in firm formation}

Bengt Johannisson (1988, 1998) has developed our understanding of the dynamics of (personal) networks in a social-theoretical understanding of the firm formation process. To sketch the role of personal networks in that process, Johannisson (1987b) departed from the paradox that the entrepreneur as an individual anarchist needing independence has to be reconciled with the image of the entrepreneur as an organizer who deals with (inter)dependencies. This paradox can be resolved by considering the entrepreneur's personal network. In a theoretical piece he compared personal networks with production and symbolic forms of social exchange networks; he argued that the specific potential of personal networks is based on affection and that they "follow no rules as they emerge tie by tie" (Johannisson 1987a, p. 11). In addition, he saw personal networks as both loosely and tightly coupled, and based on symmetrical relationships.

Using the network metaphor makes it possible to bridge the social and economic dimensions of human action. Based on Granovetter's seminal article (1973) and his argument that economic activities are socially embedded, it is reasonable to contextualize the way in which social networking can be applied to economic phenomena, and then to apply the network metaphor to entrepreneurship as an act of firm formation, and address the operation of small firms as a way of life rather than as the sole effect of rational economic behavior. Instead, the use of the network metaphor opens up the possibility of seeing an actor "as a complete human being” (Johannisson 1987a, p. 10), where all human potentials, including the affective ones, need to be taken into account.

Accordingly, Johannisson (Johannisson and Mønsted 1997) proposes an integrative view in which an individual's business and social aspects are tied together in the personal networks that entrepreneurs build. Thus running a business is as much an existential as a commercial project. As the network is personal it is also unique, since each person has his or her own special history: "[i]n a personal network, everybody is a somebody" (Johannisson 1987a, p. 12). The entrepreneur's personal network encompasses both social and business relationships; establishing and managing one's personal network mobilizes all of a person's resources. Entrepreneurs operate their firms as complete human beings, tapping all their cognitions, emotional resources and will power to initiate action (Johannisson 1988).

In the process of forming a firm, the network becomes the outcome of repeated interactions and occasional contracting which over time develop into complex ties. According to Johannisson (2000), entrepreneurs need their personal networks in order to confirm their identities and to enforce their selfconfidence as new challenges emerge. That is, networking provides them with legitimacy and creates the trustworthiness people need to build relationships, and it becomes a way for the entrepreneur to refine existing competencies. Through personal trust between economic actors, the resources the network controls become as strong as ownership control itself. In addition to refining existing competencies, networking creates new competencies which are important for reorientation and growth in the firm.

The role of the entrepreneur's personal network varies and changes over time during the process of firm formation. As long as the business remains a vision, inasmuch as entrepreneurs lack an institutional platform and are marginal with respect to existing norms, the personal network will mainly consist of the family circle and the person's closest external network. The personal network serves as a sounding board, providing social support and legitimacy, and importantly, enhancing the entrepreneur's self efficacy. As the business becomes more concrete, the direction and contents of the network will successively build the firm's resource bank: the personal network changes as the entrepreneur's identification matures. Only when the entrepreneur launches the business and experiences enough selfefficacy does it become natural to establish external relationships; at the same time the entrepreneur becomes an interesting conversational partner for external actors (Johannisson 1987a). As the business project is about to be launched, the entrepreneur operates the network proactively, supplementing his or her limited internal resources. Affective commitment becomes an important part of the entrepreneur's action-provoking relationships. And finally, when the 
business needs to be renewed, the network can be activated again in order to generate impulses for revitalization (Johannisson 1986).

The entrepreneur's personal network is the vehicle by which he or she interacts with the environment, and in this respect it makes it possible to "enact" the environment; that is, it is socially constructed by processes of attention, action and interpretation (Johannisson 1988). According to Johannisson (1988, 2000), entrepreneurs create the conditions for their own development, by enacting the environment during the firm formation process (Weick 1979). Johannisson (1988) uses the concept of "organizing context" as a clustered sociometric network creating a sense of community which supports entrepreneurs in fulfilling their existential and materialistic concerns as they form their firms. In this respect, social and/or geographic proximity facilitate the formation of networks in this organizing context. The networks help to mobilize the resources needed for entrepreneurial action, but also carry the generic function that the entrepreneur can use to balance the needs for both guidelines and independence, and for both stability and change. That is, the context helps the entrepreneur to realize and enact the firm. The context also has a symbolic function as it reduces ambiguity and increases the entrepreneur's understanding of the situation-helping make him or her more action oriented (Johannisson et al. 1994).

Two elements are vital to an efficient local network: first, a minimum number of businesses to create a certain freedom of choice in establishing personal relationships, and second, businesses doing work similar enough to create a learning environment, but different enough so they will not be regarded as competitors. However, Johannisson (1986) shows that the local network not only ties the local businesses together but tends to link business and society together, and helps to create global contacts. According to Johannisson (1994), businesses need to be both local and global in their focus, or what he and others call "glocal".

\subsection{Networks in a comparative perspective}

Johannisson also enhanced the study of networks by setting up a comparative perspective, comparing them to corporate organizations and science parks (Johannisson 1987b; Johannisson et al. 1994) or by weighing against each other networks of knowledgebased and traditional small firms (Johannisson 1998) or comparing localized small-firm clusters (Johannisson et al. 2002).

The organizing contexts vary in how efficiently they can support entrepreneurial enactment. In an empirical comparative study of an industrial district, a science park, and an innovative large company in Sweden, Johannisson et al. (1994) found that the industrial district seems to stand out as a highly integrated texture encompassing all aspects of a network, whereas the networks in the science park were neither dense nor connected, but, as expected, relatively elaborated with regard to communication and exchanges of competencies. Finally, although the innovative company seems to be even more elaborated in their exchange of competences and in communication, apparently corporate entrepreneurs cannot mobilize social resources because they have so few complex ties. Johannisson concluded that the promotion of entrepreneurship in different contexts has varying potential and reflects different organizing principles.

In another much-cited empirical study, Johannisson (1998) shows that entrepreneurs in knowledgebased firms, compared to those in traditional firms, invest more time in networking and also build more focused networks. One possible explanation might be that knowledge-based entrepreneurs build their personal networks more deliberately than traditional entrepreneurs. In addition, academic entrepreneurs in science parks establish less dense local networks than traditional entrepreneurs in industrial districts, but the differences between knowledge-based and traditional firms seem to lessen over time. On the one hand, over time, knowledge-based firms become detached from their academic commitment and more attached to the business community. On the other hand, traditional entrepreneurs become increasingly aware of the need to operate their personal networks more strategically (Johannisson 1998).

Finally, he analyzed and discussed the complexity of (spatial) contexts within two small-business communities; one is based on the furniture industry and the other represents the most advanced industrial district in Sweden with manufacturing as its core industry (Johannisson et al. 2002). He and his colleagues found that the two clusters were quite similar with respect to factors like the average size of 
the networks and the predominance of small (family) businesses, but were different in terms of network density and social embeddedness. In a small cluster the networks are denser and more often based on strong friendships. The authors concluded that small business owner-managers build personal networks where individual ties combine calculative and social concerns, and since new ventures emerge out of personal networks, institutions are literally the outcomes of social processes that reflect the local culture. Furthermore, the combination of dense local networks and globally significant firms provides competitive strength to all individual firms as well as to the larger community.

\section{Enacting an interpretive landscape of entrepreneurship studies: methodological and conceptual inventiveness}

\subsection{An emerging focus on interpretive approaches}

Bengt Johannisson anchored his academic career in the 1970s and early 1980s. However, both conceptually and methodologically, he has often loosened this anchor and explored new waters. While he continued to be interested in local development and personal networks, he began to question the conceptual and methodological foundations of entrepreneurship and small business research, and even his own earlier research. His questioning of his own scientific foundation is clearly reflected in his $1981 \mathrm{Ph} \mathrm{D}$ thesis at Gothenburg University, The Organizational Melting Pot-Competence and Handicap in Mergers, in which he documented a strong concern with methodological and conceptual questions. In the early 1980s he was also involved in research projects in prosperous regions in Sweden in which he used an action research approach (Johannisson and Spilling 1986). His concerns came into full bloom in an essay where he posed the provocative question whether researchers can understand entrepreneurship without being involved in the action itself (Johannisson 1983b).

However, it is important to stress that Johannisson never took any dogmatic position concerning paradigmatical, epistemological, conceptual and methodological issues, instead favoring what he called "a 'pragmatic' approach" (Johannisson 1995a, p. 229). That said, it still has to be pointed out that his studies of networks, local development and firm formation show more than an average level of concern for explicit paradigmatical, methodological and conceptual issues (see Johannisson 1995a; 2000; Johannisson and Mønsted 1997; Johannisson et al. 2002). This reflexivity let him approach his study of networking, organizing, learning and other social processes in a more complex and critical way. Even when he was not specifically aiming at conceptual or methodological development, he took advantage of opportunities to explore and actively support the emergence of the interpretive paradigm which had started quite hesitantly in entrepreneurship studies (Grant and Perren 2002; Steyaert 2005). Thus we think it is fair to single out his contribution to the emergence of an interpretive paradigm within entrepreneurship studies which has allowed the field to evolve into one that absorbs multiple paradigms (Steyaert 2005). We will now briefly sketch how an interpretive landscape of entrepreneurship studies becomes visible in Johannisson's work, and then introduce his project on enactive research.

\subsection{Interpretive approaches used in Johannisson's work}

Bengt Johannisson was one of the few scholars of his time to align the study of networking and other forms of social situatedness with an inquiry into new epistemological, methodological and conceptual possibilities (Johannisson 1995a; Johannisson and Mønsted 1997). He urged researchers to consider "which paradigmatic outlook is adopted" (Johannisson 1987a, p. 3). In that sense, he encouraged not only methodological but also epistemic reflexivity as "[p]roposed images of entrepreneurial networking not only reflect a special societal context, but also announce a particular paradigmatic outlook" (Johannisson and Mønsted 1997, p. 117; italics in original). Searching for ways to study the processual, complex, and delicate character of networking (Johannisson 1995a, p. 215), he increasingly referred to the possibilities an interpretive approach could offer.

Indeed, he was an early reader of Berger and Luckmann's The Social Construction of Reality (1967) and Weick's The Social Psychology of Organizing (1979); theoretically this made him one 
of the first to argue that entrepreneurship is a social constructionist process of organizing (Fletcher 2006; Steyaert 2007a). At some "clarifying" moments he opened up to other types of scholarship besides the then-dominant neo-positivism (Grant and Perren 2002). Without rejecting the latter and without stepping into the trap of having to choose between quantitative and qualitative methods (Johannisson 1995a), he clearly indicated his interest in going in another direction: "[i]f the image of organizing as an ongoing social process is to be taken seriously, approaches that are less normative and more interpretive must be applied" (Johannisson 1987a, p. 5, italics added). He developed this contextual-interpretive stance by adopting the new cultural turn in organization studies of the 1980s (Johannisson 1984) and interweaving it with the upcoming interest in sense-making perspectives, not least in Weick's theory of organizing (1979). By casting his net wider, anthropological and sociological alternatives are imported into the scope of entrepreneurial research. Encouraging scholars in entrepreneurship to "take anthropological methodology seriously" (Johannisson 1987 a, p. 8), he clearly opens up an anthropological sensitivity to studying networking processes.

Increasingly, Johannisson (1995a) has turned to a more explicit discussion of "paradigms" to stage a "critical reflection concerning (...) ontological and methodological issues" needed to apply the network metaphor (Johannisson 1995a, p. 215). Drawing upon the paradigmatic distinctions of Burrell and Morgan (1979; Grant and Perren 2002), he juxtaposes objectivist and subjectivist understandings of the functions of the entrepreneur with images of exchange networks. While he explores both paradigmatic functions in parallel, he believes that the network metaphor represents a bridging function and proposes investing in bridging methodologies, thus integrating qualitative and quantitative methods. He clearly indicates, however, that the subjectivist paradigm "is the most intriguing one" (Johannisson 1995a, p. 230) and "an understanding of genuine entrepreneurship in our mind calls for a subjectivist approach and more 'grounded' research" (p. 228). Not only does this indicate a changing personal priority; more importantly, it makes a visible plea for other kinds of paradigmatic stances by asserting that entrepreneurship, like any other social phenomenon, is idiosyncratic and that "only unprejudiced in-depth analysis can contribute to the understanding of how genuine entrepreneurship is enacted" (p. 225; italics added). While he tries to raise an awareness of the paradigms involved in entrepreneurship studies, he takes a clear position: "A subjectivist approach thus seems to be most able to exploit the potentials of the network metaphor in entrepreneurship research since venturing means organizing through personal networking" (p. 215).

Surprisingly, the 1995 article represents an important reductionist move, as he concentrates on the subjectivist versus objectivist dimension and leaves out the societal dimension of Burrell and Morgan's frame: whether scientific research is about confirming social order or oriented towards social change. It is exactly that political dimension of entrepreneurship (research) and its ideological consequences (Hjorth et al. 2003) that will become part of his further "methodological experimentation". What starts as a plea, influenced by anthropological principles of participant observation and thick description, evolves into a form of action research and the development of a "new" genre of research, so-called enactive research. He increasingly emphasizes that research occurs in the middle of society (Johannisson 2005) and that it aims to influence policy practices (Johannisson 2004).

\subsection{A "new" genre of entrepreneurship research: enactive research}

Rather than to describe enactive research theoretically, Johannisson turned to entrepreneurial action and set up an event in his own region. Discussing various interactive approaches to research, from interpreting to provoking, Johannisson acknowledged that the model of enactive research was the one he would use to develop and refine his personal theory of the entrepreneurial phenomenon. Enactive research aims at being present when a new enterprise is conceived; of course the easiest way to do this is to actually initiate the entrepreneurial event. So Johannisson suggested that the best way to study entrepreneurship is to try it out. Therefore, his research turned to the enactment of entrepreneurial events; this gave him the chance to stage new situations and later reflect on them using self- or auto-ethnography (Johannisson 2002b, 2004). Thus, he would set up an event to stimulate local development and create a 
meeting between art and science. Working with a team, he organized an art exhibition and a series of seminars. He published his reflections on this entrepreneurial endeavor in a monograph entitled "The essence of entrepreneurship" (in Swedish) (Johannisson 2005), an unusual genre for him. However, he says, that this book portrays the most important adventure of his life and contains the most significant stories he can tell about entrepreneurship. Not surprisingly, this event forms the core point of departure for his award-winning lecture (Johannisson 2009).

With this project on enactive research his career comes full circle. His early interest in community development (Johannisson and Spilling 1986; Johannisson and Nilsson 1989) evolved into a search for different ways to stimulate and study complex community-development processes (Johannisson 2007b). As he engaged, hands-on, in ongoing entrepreneurial events and set up collaboration between local stakeholders and researchers, he moved his research into a realm that was more practical and politically relevant. Thus, enactive research is his new style of participative research, underlining that all "interactive research can help make university researchers more critical and more useful" (Johannisson 2004, p. 13). With this emphasis on enactive research, Johannisson (2009) uses the Aristotelian notion of phronesis or practical wisdom, as the way to blur, entwine and hook up theory and practice, and to update his life-long vision that entrepreneurship is a matter of (inter)activity.

\section{The future of entrepreneurship studies as an adventure}

Reviewing the academic work of Bengt Johannisson from the perspective of entrepreneurship as social practice, we have emphasized the pioneering, provocative and participative dimensions that we see running through his academic work like an entangled red thread. Our assessment might be further strengthened and illustrated by the way he framed the final issue (Johannisson 2007a) of Entrepreneurship and Regional Development that he edited; it can be read both as testimony to and testimonial for his academic beliefs. Rather than prepare himself and his readers for a farewell and create the grateful send-off message that one might expect on such an occasion, he refuses to take refuge in looking back, but instead quite frankly and radically looks forward, eager to reveal his "hidden personal aspirations as regards future contributions to the journal" (p. 451). As he sees himself as editor "in charge of exploring lands which are beyond the contemporary frontline" (p. 451), there seem to be no limits to (t)his pioneering energy to explore and open new grounds. He illustrated this with his title- "Pioneering new fields of entrepreneurship research" (italics added) which was developed by Steyaert (2007a) in a conceptual piece on "entrepreneuring", a process theory that applies social ontology and epistemology to entrepreneurship. His sense of provocation and engagement is illustrated in the critical papers by Anderson and Smith (2007) on the ethical imperative and moral legitimacy of enterprising discourses and by Berglund and Johansson (2007) on the exclusionary effect of enterprise discourse in the context of regional development. He also co-authored a final collective paper with 13 -yes, that is correctdoctoral students (Johannisson et al. 2007) based on "the interplay between research, education and community dialogue" (Johannisson 2007a, p. 452). The quartet of papers of this parting, special issue thus shows the kind of integration that Johannisson seeks: an approach to entrepreneurship that combines conceptual innovation, ethical engagement and experimental participation, and which all too often has remained disconnected in his broad oeuvre. Johannisson's legacy is not about the past, but instead pushes us to see the future of entrepreneurship studies as an adventure.

While Johannisson looks forward, we have been looking backwards in this article, re-reading his work. If you want to understand a scholar, you have to read all of his work, and probably also the works he was having on his desk while writing, as Gilles Deleuze and Félix Guattari once remarked. In the case of Bengt Johannisson there is a lot to read and to draw from. We are aware that with the focus we have set and the red thread we have created, we have overlooked several possibilities. To appreciate Johannisson's work as an oeuvre, we have not tried to make a "total" interpretation but have singled out the period of the 1980s and the later moves that can be seen in his writings. This has allowed us to reconstruct, by reading through his unfolding line of 
argumentation, a crucial transition in the history of entrepreneurship studies: the emergence of an interpretive study of the sociality of the entrepreneurial phenomenon.

It is quite obvious to us that his pioneering role lies quite precisely in his timely reading and application of a processual way of thinking about entrepreneurship as it was emerging in texts on the social construction of reality as organizing that occurs through enactment and interpretation (Landström 2005). He is not unique in reading and applying these new textual signs-parallels exist, for instance, to the Weickian inspired work of Gartner (see Gartner 2004; Hjorth and Johannisson 2008). But while Gartner was countering the individualist obsession of entrepreneurship scholars (Gartner 1988) and making space for processual frameworks (Gartner 1985); Johannisson (1987a, 1987b) was actively exploring alternative, more socially-oriented understandings of entrepreneurship by enacting another object of entrepreneurship studies: the process of networking.

By linking a focus on networking as an enactment of local development with a contextual-interpretive framework, Johannisson resisted the possibility that the European entrepreneurship research scene would become reduced to, if not colonized by, an AngloSaxon, neo-positivist model. Thus, in the 1980s he was already using a model for researching entrepreneurship that is only today becoming apparent as an alternative for the individualist conception of the entrepreneurial discourse and that grounds entrepreneurship in a social ontology (Steyaert 2007a). If Johannisson is eager, in his next move of looking forward to and anticipating the future, to dedicate his insightful prize lecture to the possibility of connecting entrepreneurship to the practice turn in the social sciences (Schatzki 2001; Bourdieu 1992), he will again show his pioneering competence, and also provoke entrepreneurship studies to take creative steps in its own evolution and to participate in new ways of enacting research. If Bengt Johannisson has paved the way for a practice theory of entrepreneuring, he is also witty enough to declare it as his testimonial enunciation of the future. If enactive research consists of interpreting during and after doing, his career of somewhat scattered research enactments and valuable experiments has found a vision for the future, and no one in entrepreneurship research who values thinking at the boundary will be able to disregard it.

\section{References}

Aldrich, H., \& Zimmer, C. (1986). Entrepreneurship through social networks. In D. Sexton \& R. Smilor (Eds.), The art and science of entrepreneurship (pp. 3-23). New York: Ballinger.

Anderson, A. R., \& Smith, R. (2007). The moral space in entrepreneurship: An exploration of ethical imperatives and the moral legitimacy of being enterprising. Entrepreneurship and Regional Development, 19(6), 479-497.

Becattini, G. (1989). Sectors and/or districts: Some remarks on the conceptual foundations of industrial economics. In E. Goodman, J. Bamford, \& P. Saynor (Eds.), Small firms and industrial districts in Italy (pp. 123-135). London: Routledge.

Berger, P., \& Luckmann, T. (1967). The social construction of reality. New York: Doubleday.

Berglund, K., \& Johansson, A. W. (2007). Entrepreneurship, discourses and conscientization in processes of regional development. Entrepreneurship and Regional Development, 19(6), 499-525.

Birch, D. L. (1979). The job generation process. Cambridge, MA: MIT Program on Neighborhood and Regional Change.

Birley, S. (1985). The role of networks in the entrepreneurial process. Journal of Business Venturing, 1(1), 107-117.

Bourdieu, P. (1992). The logic of practice. Cambridge: Polity Press.

Brusco, S. (1989). A policy for industrial districts. In E. Goodman, J. Bamford, \& P. Saynor (Eds.), Small firms and industrial districts in Italy (pp. 259-269). London: Routledge.

Burrell, G., \& Morgan, G. (1979). Sociological paradigms and organizational analysis. Aldershot: Gower.

Fletcher, D. (2006). Entrepreneurial processes and the social construction of opportunity. Entrepreneurship and Regional Development, 18(5), 421-440.

Gartner, W. B. (1985). A conceptual framework for describing the phenomenon of new venture creation. Academy of Management Review, 10(4), 696-706.

Gartner, W. B. (1988). "Who is an entrepreneur?" is the wrong question. American Journal of Small Business, 12(4), 1132.

Gartner, W. B. (2004). The edge defines the (w)hole: Saying what entrepreneurship is (not). In D. Hjorth \& C. Steyaert (Eds.), Narrative and discursive approaches in entrepreneurship (pp. 245-254). Cheltenham: Edward Elgar.

Gartner, W. B., Bird, B. J., \& Starr, J. A. (1992). Acting 'as if': Differentiating entrepreneurial from organizational behavior. Entrepreneurship Theory and Practice, 16(3), 13-31.

Geertz, C. (1983). Local knowledge. New York: Basic Books.

Glaser, B. G., \& Strauss, A. L. (1967). The discovery of grounded theory. Chicago: Aldine. 
Goodman, E., Bamford, J., \& Saynor, P. (1989). Small firms and industrial districts in Italy. London: Routledge.

Granovetter, M. (1973). The strength of weak ties. American Journal of Sociology, 78(6), 1360-1380.

Grant, P., \& Perren, L. (2002). Small business and entrepreneurship research: meta-theories, paradigms and prejudices. International Small Business Journal, 20(2), 185211.

Hjorth, D., Campbell, J., \& Gartner, B. (2008). Introduction for 'recreating/recontextualising' entrepreneurship. Scandinavian Journal of Management, 24(2), 81-84.

Hjorth, D., \& Johannisson, B. (2008). Building new roads for entrepreneurship to travel by: on the work of William B Gartner. Small Business Economics, 31(4), 341-350.

Hjorth, D., Johannisson, B., \& Steyaert, C. (2003). Entrepreneurship as discourse and life style. In B. Czarniawska \& G. Sevon (Eds.), The northern lights. Organization theory in Scandinavia (pp. 91-110). Malmö: Liber.

Jack, S., Drakopoulou, S., \& Anderson, A. R. (2008). Change and the development of entrepreneurial networks over time: A processual perspective. Entrepreneurship and Regional Development, 20(2), 125-159.

Johannisson, B. (1983a). Swedish evidence for the potential of local entrepreneurship in regional development. European Small Business Journal, 1(2), 11-24.

Johannisson, B. (1983b). Kan forskare alls begripa företagande? (Are Researchers able to Understand Entrepreneurship?). Tvärsnitt, 2, 36-41.

Johannisson, B. (1984). A cultural perspective on small business-local business climate. International Small Business Journal, 2(2), 32-43.

Johannisson, B. (1986). Network strategies: Management technology for entrepreneurship and change. International Small Business Journal, 5(1), 19-30.

Johannisson, B. (1987a). Beyond process and structure: Social exchange networks. International Studies of Management and Organization, 17(1), 3-23.

Johannisson, B. (1987b). Anarchists and organizers: Entrepreneurs in a network perspective. International Studies of Management and Organization, 17(1), 49-63.

Johannisson, B. (1988). Business formation-A network approach. Scandinavian Journal of Management, 4(3/4), 83-99.

Johannisson, B. (1994). Building a 'glocal' strategy. Internationalizing small firms through local networking. Small Business and its Contribution to Regional and International Development. In: Proceedings of the 39th ICSB Annual World Conference, Strassbourg, pp. 137-135.

Johannisson, B. (1995a). Paradigms and entrepreneurial networks - some methodological challenges. Entrepreneurship and Regional Development, 7(3), 215-232.

Johannisson, B. (1995b). Entrepreneurial networking in the Scandinavian context: Theoretical and empirical positioning. Entrepreneurship and Regional Development, 7(3), 189-192.

Johannisson, B. (1998). Personal networks in emerging knowledge-based firms: spatial and functional patterns. Entrepreneurship and Regional Development, 10(4), 297-312.

Johannisson B. (1999). The future of entrepreneurship research. An European perspective. Keynote speech at the RENT XIII Conference, London.
Johannisson, B. (2000). Networking and entrepreneurial growth. In D. L. Sexton \& H. Landström (Eds.), The Blackwell handbook of entrepreneurship (pp. 368-386). Oxford: Blackwell.

Johannisson, B. (2002a). Entrepreneurship in a network perspective. Plenary presentation at the 12 th Nordic Workshop on Interorganisational Research, Kolding.

Johannisson, B. (2002b). Enacting entrepreneurship-Using auto-ethnography to study organization creation. Paper presented at the conference Ethnographic Organizational Studies, St Gallen, Switzerland.

Johannisson, B. (2004). Between arm's length research and policy practices-Interactive approaches in Entrepreneurship Studies. Paper presented at the 13th Nordic Conference on Small Business Research, Tromsö, Norway.

Johannisson, B. (2005). Entreprenörskapets väsen (The essence of entrepreneurship). Lund: Studentlitteratur.

Johannisson, B. (2007a). Editorial. Entrepreneurship and Regional Development, 19(6), 451-452.

Johannisson, B. (2007b). Enacting local economic development-theoretical and methodological challenges. Journal of Enterprising Communities, 1(1), 7-26.

Johannisson, B. (2009). Towards a practice theory of entrepreneuring. Small Business Economics, forthcoming.

Johannisson, B., Alexanderson, O., Nowicki, K., \& Senneseth, K. (1994). Beyond anarchy and organization: Entrepreneurs in contextual networks. Entrepreneurship and Regional Development, 6(4), 329-356.

Johannisson, B., \& Mønsted, M. (1997). Contextualizing entrepreneurial networking. International Studies of Management and Organization, 27(3), 109-136.

Johannisson, B., \& Nilsson, A. (1989). Community entrepreneurship_-Networking for local development. Entrepreneurship and Regional Development, 1(1), 1-19.

Johannisson, B., Ramirez-Pasillas, M., \& Karlsson, G. (2002). Institutional embeddedness of inter-firm networks: A leverage for business creation. Entrepreneurship and Regional Development, 14(4), 297-315.

Johannisson, B., \& Spilling, O. (Eds.). (1986). Lokal naeringsutveckling (Local economic development). Oslo: Universitetsforlaget.

Johannisson, B., et al. (2007). Interstanding the industrial district: Contrasting conceptual images as a road to insight. Entrepreneurship and Regional Development, 19(6), 527-554.

Karlsson, C., Johannisson, B., \& Storey, D. (1993). Small business dynamics. International, national and regional perspectives. London: Routledge.

Landström, H. (2005). Pioneers in entrepreneurship and small business research. New York: Springer.

Landström, H., \& Johannisson, B. (1999). Images of entrepreneurship and small business research. Emergent Swedish contributions to academic research. Lund: Studentlitteratur.

Landström, H., \& Johannisson, B. (2001). Theoretical foundations of Swedish entrepreneurship and small-business research. Scandinavian Journal of Management, 17(2), 225-248.

Marshall, A. (1919). Industry and trade. London: Macmillan.

Piore, M. J., \& Sabel, C. F. (1984). The second industrial divide. Possibilities for prosperity. New York: Basic Books. 
Schatzki, T. R. (2001). Introduction: Practice theory. In T. R. Schatzki, K. Knorr Cetina, \& E. von Savigny (Eds.), The practice turn in contemporary theory (pp. 1-14). London: Routledge.

Steyaert, C. (2005). Entrepreneurship: In between what? on the "frontier" as a discourse of entrepreneurship research. International Journal of Entrepreneurship and Small Business, 2(1), 2-16.

Steyaert, C. (2007a). Entrepreneuring as a conceptual attractor?: A review of process theories in 20 years of entrepreneurship studies? Entrepreneurship and Regional Development, 19(6), 453-477.
Steyaert, C. (2007b). Of course that is not the whole (toy) story: Entrepreneurship and the cat's cradle. Journal of Business Venturing, 22(5), 733-751.

Urbano, D., Aponte, M., \& Toledano, N. (2008). Doctoral education in entrepreneurship: A European case study. Journal of Small Business and Enterprise Development, 15(2), 336-347.

Weber, A. (1909). Theory of the location of industries. Chicago: Chicago University Press.

Weick, K. E. (1979). The social psychology of organizing. Reading, MA: Addison-Wesley. 